\title{
STRATEGI MENINGKATKAN PEMAHAMAN MAHASISWA TERKAIT LITERASI PASAR MODAL SYARIAH MELALUI KEGIATAN KSPM
}

\author{
Anik Gita Yuana1 \\ Ato'illah Shohibul Hikam² \\ Moh Agung Maulana Iswanto ${ }^{3}$ \\ Yulida Fithriyatul Maini4 \\ Manajemen Keuangan Syariah, Fakultas Ekonomi dan Bisnis Islam, Universitas Islam Zainul \\ Hasan, Probolinggo Jawa Timur. \\ Email: anikgita345@gmail.com ${ }^{1}$; kconk794@gmail.com²; agung.mln27@gmail.com³; \\ yulidafithriyatulm@gmail.com ${ }^{4}$
}

\begin{abstract}
Introduction: The purpose of this study is to increase students' understanding of Islamic capital market literacy, where currently the level of public knowledge, especially Islamic economics, does not increase significantly. Data obtained from the Financial Services Authority (OJK) states that in 2016, the Indonesian people's literacy index was $21.8 \%$, meaning that out of 100 Indonesians who understand Islamic financial literacy, only 21 people, in 2018 the literacy index reached 29.7\%, in 2020 the Islamic financial literacy index reached $38.03 \%$.

Methods: The research method in this paper is a qualitative research, with the data collection is interviews. This type of sampling uses probability sampling, meaning that the researcher takes a random sample of 50 population members of the Islamic capital market group (KSPM) from various study programs at the Zainul Hasan Genggong Islamic University.

Results: The results show that the study conducted by the capital market group which is held every 3 months has increased knowledge by members regarding the Islamic capital market, and every 6 months a capital market school will be held by the UNZAH investment gallery and the presenters are from the IDX (Indonesian Stock Exchange).
\end{abstract}

Keywords: KSPM, Literacy, Islamic Capital Market

\section{PENDAHULUAN}

Perekonomian syariah sangat gencar digaungkan mulai tahun 2010 silam, hingga saat ini pun perkembangan ekonomi syariah ditambah keuangan syariah sangatlah signifikan. Kondisi ini diperkuat dengan dibentuknya lembaga non struktural yang diketuai langsung oleh bapak presiden Joko Widodo yang bernama KNKS (Komite Nasional Keuangan Syariah) pada tanggal 8 november 2016, kemudian pada tanggal 10 
pebruari 2020, nama KNKS diubah menjadi Komite Nasional Ekonomi dan Keuangan Syariah yang mana bertujuan untuk meningkatkan pembangunan ekosistem ekonomi dan keuangan syariah dalam rangka memajukan perekonomian nasional dikancah global.

Perekonomian tidak terlepas dari kegiatan investasi. Investasi di Indonesia meningkat sejalan dengan perkembangan inklusi keuangan, akan tetapi investasi syariah perkembangannya sangat rendah. Jumlah investor syariah dikutip dari liputan 6.com masih sangat kecil per juni 2021, yaitu hanya 4,1\% dibandingkan dari total investor yang bukan syariah. Kecilnya angka investor syariah disebabkan karena tingkat literasi dan inklusi keuangan syariah yang masih sangat rendah. Berdasarkan survey nasional keuangan Indonesia tahun 2019 yang dilakukan oleh OJK tingkat literasi keuangan syariah hanya dikisaran 8,93\% sedangkan inklusi keuangan syariah di angka 9,10\% dengan kata lain hanya 9 dari 100 orang dewasa Indonesia yang mengenal produk keuangan syariah dengan baik. Semenatara itu pada tahun 2013, dan 2016 indeks literasi dan inklusi keuangan menunjukkan adanya kenaikan dari tahun ke tahun namun tidak signifikan. Pada tahun 2013 indeks literasi masyarakat Indonesia adalah 21,8\% atau dari 100 penduduk Indonesia hanya sekitar 21 orang yang memiliki pengetahuan, keterampilan dan kepercayaan terhadap produk dan jasa keuangan, sedangkan indeks inklusi 59,7\% atau dari 100 penduduk Indonesia hanya sekitar 59 orang yang menggunakan dan memiliki produk lembaga keuangan. Pada tahun 2016, indeks literasi mencapai $29,7 \%$ dan indeks inklusi mencapai $67,8 \%{ }^{1}$ Perkembangan inklusi syariah tidak diimbangi dengan perkembangan literasi keuangan syariah, padahal negara Indonesia merupakan negara dengan mayoritas penduduknya yang beragama Islam. Namun dalam perkembangan 5 tahun ini, kapitalisasi pasar saham-saham syariah yang tercatat di Bursa Efek Indonesia meningkat 28,62\% dalam lima tahun menjadi 3,344 triliun pada 2020, sementara itu produk reksa dana syariah melonjak hingga 574\% menjadi Rp 74,37 triliun pada 2020. ${ }^{2}$ Tantangan itulah yang dimiliki Indonesia saat ini, disamping tantangan ada peluang yang harus di fokuskan terkait dunia pasar modal. Bonus demografi Indonesia pada tahun 2020 didominasi oleh generasi Z, dimana total generasi ini terdapat 74,93 juta atau sekitar $27,94 \%$ dari total penduduk Indonesia. Generasi Z berusia 8 hingga 23 tahun, usia generasi Z belum semua memasuki usia produktif, akan tetapi sekitar 7 tahun lagi mereka akan memasuki usia produktif. Kemudian komposisi penduduk terbesar selanjutnya berada di usia produktif, yaitu milenial sebanyak 69,38 juta atau 25,87\% yaitu mereka yang berusia diatas 23 tahun hingga 30 an keatas, dan yang terakhir adalah generasi X sekitar 58,65 juta atau 21,88\%. Seperti grafik dibawah ini.

\footnotetext{
${ }^{1}$ Modal, P. E. K. S. P., Investor, W., Indikator, D. A. P. S. S., \& Investasi, K. FAKULTAS EKONOMI DAN BISNIS ISLAM UNIVERSITAS ISLAM NEGERI WALISONGO SEMARANG.

${ }^{2}$ Mawardi, M., \& Lemiyana, L. (2020). Edukasi Pasar Modal Syariah untuk Menumbuhkan Minat Investasi bagi Mahasiswa UIN Raden Fatah Palembang. Jurnal Pengabdian Pada Masyarakat, 5(2), 529-537.
} 


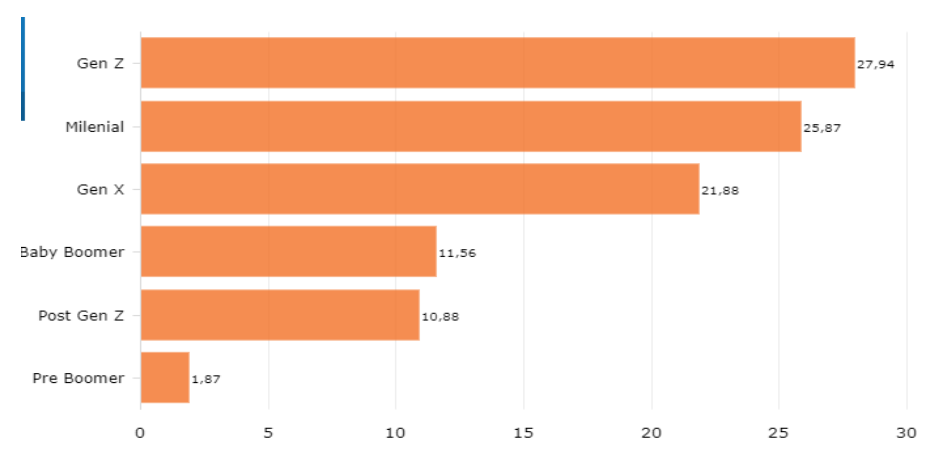

Gambar 1: Perkembangan Generasi

Banyaknya jumlah generasi $\mathrm{Z}$ dan milenial mempengaruhi banyaknya investor pasar modal syariah, apalagi saat kondisi pandemi covid-19,dikarenakan generasi ini merupakan generasi tertinggi dalam menggunakan internet. Survey menyebutkan bahwasannya generasi Z menghabiskan waktu minimal 4 jam sehari untuk mengakses internet. Kelompok Sekolah Pasar Modal fakultas ekonomi dan bisnis universitas islam zainul hasan genggong menjadi kegiatan intra kampus yang didirikan setelah pembentukan Galeri Investasi Bursa Efek Indonesia Universitas Islam Zainul Hasan Genggong oleh sekelompok dosen F.E.B.I pada tahun 2018, yang bertujuan untuk mewadahi pengetahuan mahasiswa dalam bidang pasar modal dan mampu mempraktikkannya karena dalam kurikulum fakultas ekonomi dan bisnis islam UNZAH terdapat matakuliah manajemen investasi dan pasar modal syariah pada semester 5 dan 6. Kemudian pada pertengahan tahun 2019, didirikanlah Kelompok Sekolah Pasar Modal dengan keseluruhan berjumlah 50 anggota sampai saat ini dari berbagai fakultas yaitu fakultas ekonomi dan bisnis islam, tarbiyah, tadris umum dan syariah di kampus UNZAH. Kelompok sekolah pasar modal bertujuan untuk mewadahi mahasiswa agar memahami praktik pasar modal sebenarnya beserta produk-produk yang dijual pada pasar modal baik konvensioanl dan syariah.

Menuju Indonesia emas 2045, Sri Mulyani berpendapat Indonesia diprediksi akan mengalami bonyus demografi, yaitu dimana jumlah penduduk produktif (15-64 tahun) lebih besar dibandingkan penduduk usia tidak produktif (dibawah 15 tahun dan diatas 64 tahun) maka maka kondisi ini sesuai dengan diatas, yang sudah disebutkan, yaitu Indonesia akan dihuni oleh mayoritas generasi $\mathrm{Z}$ dan generasi milenial, maka dari itu dibutuhkan pengetahuan yang mumpuni mengenai pengelolaan keuangan yang baik serta memahami berbagai instrument keuangan dan ilmu pengetahuan ekonomi dasar, sehingga setiap keputusan akan diambil berdasarkan fakta maupun data yang mana akan menjadikan Indonesia menjadi salah satu Negara dengan perekonomian terkuat di dunia. Maka dari itu untuk mewujudkan tujuan tersebut didrikanlah kelompok sekolah pasar modal di kampus-kampus. Dari latar belakang diatas, maka diambil judul "Strategi Meningkatkan Pemahaman Mahasiswa Terkait Literasi Pasar Modal Syariah Melalui 
Kegiatan KSPM Kelompok Sekolah Pasar Modal, Studi pada mahasiswa anggota KSPM Universitas Islam Zainul Hasan Genggong Probolinggo.

\section{TINJAUAN PUSTAKA}

\section{Investasi}

Investasi Investasi berasal dari kata invest yang berarti menanam atau menginvestasikan uang atau modal. Secara umum investasi atau penanaman modal dapat diartikan sebagai suatu kegiatan yang dilakukan baik oleh orang pribadi (natural person) maupun badan hukum (juridical person) dalam upaya untuk meningkatkan dan/atau mempertahankan nilai modalnya, baik yang berbentuk uang tunai (cash money), peralatan (equipment), aset tidak bergerak, hak atas kekayaan intelektual, maupun keahlian. Menurut Relly dan Brown, dalam tulisan Irham Fahmi memberikan pengertian investasi adalah, "Investment is the current commitment of doller for a period of time to derive future payment that will compensate the investor for (1) the time funds are commited, (2) the expected rate of inflation, (3) the uncertainty of the future payment". ${ }^{3}$ Adapun menurut Abdul Halim dalam Irham Fahmi investasi pada hakikatnya merupakan penempatan sejumlah dana dengan harapan memperoleh keuntungan di masa mendatang. Investasi menurut definisi adalah menanamkan atau menempatkan asset, baik berupa harta maupun dana, pada sesuatu yang di harapkan akan memberikan hasil pendapatan atau akan meningkatkan nilainya di masa mendatang. ${ }^{4}$ Dapat di simpulkan investasi adalah penanaman modal atau menempatkan aset, baik berupa harta maupun dana, pada sesuatu yang di harapkan akan memberikan hasil pendapatan atau akan meningkatkan nilainya di masa mendatang yang dilakukan baik oleh orang pribadi (natural person) maupun badan hukum (juridical person)

\section{Pasar Modal Syariah}

Pengantar Pasar Modal Syariah Pada saat-saat awal, prinsip syariah ditetapkan pada industri perbankan, yaitu ditandai dengan didirikannya bank Islam pertama di Kairo pada sekitar tahun 1971 dengan nama Nasser Social Bank, yang operasionalnya berdasarkan bagi hasil (tanpa riba). Perkembangan bank yang berbasis syariah tersebut, ternyata ikut mendorong perkembangan penggunaan prinsip-prinsip syariah di sektor pasar modal. Kegiatan pasar modal Undang-Undang Pasar Modal (UUPM)tidak membedakan apakah kegiatan pasar modal tersebut dilakukan dengan prinsip-prinsip syariah atau tidak. Pasar modal berbasis syariah di Indonesia secara resmi diluncurkan pada tanggal 14 Maret 2003 bersamaan dengan penandatanganan MOU antara Bapepam-LK dengan Dewan

\footnotetext{
${ }^{3}$ Fahmi, Irhan. 2006. Analisis Investasi dalam Perspektif Ekonomi dan politik. Bandung : PT Refika Aditama

${ }^{4}$ Sutedi, Adrian. 2011. Pasar Modal Syariah: sarana investasi keuangan berdasarkan prinsip syariah. Jakarta: Sinar Grafik
} 
Syariah Nasional Majelis Ulama Indonesia (DSN-MUI). ${ }^{5}$ Adapun pasar modal syariah secara sederhana dapat diartikan sebagai pasar modal yang menerapkan prinsip-prinsip syariah dalam kegiatan transaksi ekonomi dan terlepas dari hal-hal yang dilarang oleh syariat, seperti unsur riba, perjudian, bersifat spekulasi, dan lainlain. Pasar modal syariah adalah pasar modal yang seluruh mekanisme kegiatannya, terutama mengenai emiten, jenis efek yang diperdagangkan dan mekanisme perdagangannya telah sesuai dengan prinsip-prinsip syariah. ${ }^{6}$

\section{METODE PENELITIAN}

Jenis penelitian ini adalah penelitian kualitatif deskriptif, yaitu data yang dikumpulkan berbentuk kata-kata, gambar, bukan angka-angka. ${ }^{7}$ Menurut Bogdan dan Taylor, sebagaimana yang dikutip oleh Lexy J. Moleong, penelitian kualitatif adalah prosedur penelitian yang menghasilkan data deskriptif berupa kata-kata tertulis atau lisan dari orang-orang dan perilaku yang diamati. ${ }^{8}$ Sementara itu, penelitian deskriptif adalah suatu bentuk penelitian yang ditujukan untuk mendeskripsikan atau menggambarkan fenomena-fenomena yang ada, baik fenomena alamiah maupun rekayasa manusia. ${ }^{9}$

Adapun tujuan dari penelitian deskriptif adalah untuk membuat pencandraan secara sistematis, faktual, dan akurat mengenai fakta dan sifat populasi atau daerah tertentu. Penelitian ini digunakan untuk mengetahui bagaimana strategis meningkatkan pemahaman terkait literasi pasar modal. Tehnik pengumpulan data menggunakan tehnik wawancara. Dalam penelitian ini metode pengambilan sampel yaitu dengan metode purposive sampling yaitu dengan mengambil secara acak/random anggota KSPM dari 4 fakultas yang terdiri dari anggota aktif, yaitu F.E.B.I terdiri dari 20 anggota aktif, fakultas tarbiyah terdiri dari 5 anggota aktif, fakultas tadris umum terdiri dari 10 anggota aktif, yang terakhir adalah fakultas syariah terdiri dari 5 anggota aktif. Lokasi penelitian adalah tempat di mana penelitian akan dilakukan. Yaitu di Universitas Islam Zainul Hasan Genggong. Penelitian ini dilakukan pada tanggal 15 - 28 Oktober 2021.

Pengertian teknik pengumpulan data menurut Arikunto adalah cara-cara yang dapat digunakan oleh peneliti untuk mengumpulkan data, di mana cara tersebut menunjukan pada suatu yang abstrak, tidak dapat di wujudkan dalam benda yang kasat mata, tetapi dapat

\footnotetext{
${ }^{5}$ Sutedi, Adrian. 2011. Pasar Modal Syariah: sarana investasi keuangan berdasarkan prinsip syariah. Jakarta: Sinar Grafik

${ }^{6}$ Sudarsono, Heri. 2012. Bank dan Lembaga Keuangan Syariah. Bandung: CV Pustaka Setia

${ }^{7}$ Sudarwan Danim, Menjadi Peneliti Kualitatif Rancangan Metodologi, Presentasi, dan Publikasi Hasil Penelitian untuk Mahasiswa dan Penelitian Pemula Bidang Ilmu Sosial, Pendidikan, dan Humaniora, (Bandung: Remaja Rosdakarya, 2002), Cet. I, hIm. 51.

${ }^{8}$ Lexy. J. Moleong, Metodologi Penelitian Kualitatif, (Bandung: PT Remaja Rosdakarya, 2000), hlm.

${ }^{9}$ Lexy. J. Moleong, Metodologi Penelitian Kualitatif, hlm. 17.
} 
dipertontonkan penggunaannya ${ }^{10}$. Dalam hal metode penelitian, peneliti langsung terjun langsung untuk menemukan data yang valid,maka peneliti menggunakan metode berikut: Pertama, Observasi atau pengamatan Dapat diartikan sebagai pengamatan dan pencatatan secara sistematis terhadap gejala yang tampak pada objek penelitian. Observasi ini menggunakan observasi partisipasi, di mana peneliti terlibat langsung dengan kegiatan seharihari orang yang sedang diamati atau yang digunakan sebagai sumber data penelitian ${ }^{11}$. Dalam observasi secara langsung ini, peneliti selain berlaku sebagai pengamat penuh yang dapat melakukan pengamatan terhadap gejala atau proses yang terjadi di dalam situasi yang sebenarnya yang langsung diamati oleh observer, juga sebagai pemeran serta atau partisipan yang ikut serta dalam.kegiatan KSPM di galeri bursa serta dalam praktek di bursa efek kampus Observasi langsung ini dilakukan peneliti untuk mengoptimalkan agar mendapatkan data data sesuai realitas kegiatan KSPM, Kedua Metode Wawancara (Interview) Wawancara adalah percakapan dengan maksud tertentu yang dilakukan oleh dua pihak, yaitu pewawancara (interviewer) yang mengajukan pertanyaan dan yang diwawancarai (interviewee) yang memberikan jawaban atas pertanyaan ${ }^{12}$.Dalam melaksanakan teknik wawancara. (interview), pewawancara harus mampu menciptakan hubungan yang baik sehingga informan bersedia bekerja sama, dan merasa bebas berbicara dan dapat memberikan informasi yang sebenarnya. yang akan disampaikan kepada informan. Dalam penelitian ini, peneliti melakukan wawancara kepada seluruh anggota aktif dan pengurus serta pembina KSPM yaitu satu dosen Fakultas Ekonomi dan Bisnis Islam yaitu Ibu Waqi'atul Aqidah, M.Pd.

\section{HASIL DAN PEMBAHASAN}

\section{Sejarah Perkembangan}

Universitas Islam Zainul Hasan Genggong merupakan perguruan tinggi yang notabelnya berbasis Syar'i. Universitas Islam Zainul Hasan Genggong memiliki 4 fakultas yaitu fakultas tarbiyah, fakultas tadris umum, fakultas syariah dan fakultas ekonomi dan bisnis Islam (FEBI) yang terdiri dari tiga prodi yaitu ekonomi syari'ah perbankan syari'ah dan manajemen keuangan syari'ah. Terkhusus mahasiswa FEBI tentu mereka tidak akan asing lagi dengan mata kuliah ekonomi, bahkan jelas itu adalah menu utama bagi mereka. Dalam sejarah pencapaiannya mahasiswa FEBI diharapkan mampu memahami setiap pembahasan materi ekonomi. Akan tetapi pemahaman mahasiswa mengenai pasar modal khususnya pasar modal syariah masih bisa di katakan minim, apalagi mahasiswa yang masih menempuh semestar awal. Dalam fakultas ekonomi mahasiswa akan mempelajari mata kuliah pasar modal ketika mereka telah mencapai semester 5 dan 6 , maka dari itu untuk mereka hanya bisa mencari alternatif lain guna mengisi pemahaman

\footnotetext{
${ }^{10}$ Suharsimi Arikunto, Prosedur Penelitian Suatu Pendekatan Praktek, (Jakarta : PT. Rineka Cipta, 2002, Cet.XII), hlm. 134.

${ }^{11}$ Sugiyono, Metode Penelitian Pendidikan; Pendekatan Kuantitatif dan Kualitatif dan R\&D , (Bandung: Alfabeta, 2006), hlm. 310.

${ }^{12}$ Lexy. J. Moleong, Metodologi Penelitian Kualitatif, (Bandung: PT Remaja Rosdakarya, 2000), hlm. 135.
} 
mereka terkait pasar modal. Pasar modal sangat penting dalam mengatasi krisis financial terutama dalam menjawab tantang inflasi bagi negara. Untuk mahasiswa di luar fakultas ekonomi dan bisnis Islam, istilah pasar modal sangatlah terlihat awam. Oleh karenanya pengetahuan yang sifatnya terapan atau aplikatif sanagtlah dibutuhkan dalam pembelajaran sehari-hari.

Seiring dengan berkembangnya zaman, kemajuan teknologi informasi kian meningkat, jejak digital yang terus berjalan kini telah memudahkan para pelajar dalam mengenal pasar modal baik secara sistematis maupun autodidak. Ditambah lagi dengan adanya kontribusi dari kspm melalui galeri investasi, diharapkan bisa menjadi jawaban dalam memberikan pemahaman bagi mahasiswa mengenai pasar modal khususnya pasar modal syari'ah. Oleh karenanya Universitas Islam Zainul Hasan Genggong mendirikan Galeri Investasi Bursa Efek Indonesia (G.I-BEI) yang bekerjasama dengan perusahaan sekuritas yaitu Phintraco securitas mulai tahun 2018, yang mana kemudian pada tahun 2019 didirikanlah kelompok sekolah pasar modal untuk mengenalkan pengetahuan seputar pasar modal baik konvemsional maupun syariah kepada mahasiswa serta praktiknya. Anggota tetap terdiri dari 50 mahasiswa dari 4 fakultas di universitas Islam Zainul Hasan Genggong.

\section{Jenjang strategi}

Galeri investasi pada umumnya adalah tempat bagi mahasiswa yang berfokus dalam dunia pasar modal. Minat berinvestasi akan dapat meningkat seiring dengan berkembangnya pemahaman mahasiswa. KSPM merupakan organisasi kemahasiswaan intra kampus, dalam skala besar peran KSPM adalah untuk mengukur pemahaman mahasiswa terkait pasar modal. Strategi mereka yaitu pendekatan dengan melakukan tindakan persuasive kepada mahasiswa dengan bahasan yang berorientasi profit (menguntungkan/uang). Rekrutmen anggota terkonsep layaknya sosialisasi merupakan kegiatan yang bertujuan untuk memunculkan ketertarikan terhadap KSPM.

Dalam langkah ini mahasiswa kemudian akan dikenalkan dengan gerbang pertama mereka yaitu PENIBA (Diklat Penerimaan Anggota Baru) Kegiatan ini bertujuan untuk memberikan pemahaman secara dasar terkait pasar modal yang kemudian menjadi tindak lanjut dari strategi edukasi. Setiap satu minggu sekali anggota akan mempelajari materi pasar modal dengan metode praktik. Kalkulasi keuangan serta menentukan harga saham merupakan bahasan yang menjadi fokus dalam materi pembelajaran ini. Melalui akun RTI (Revolusi Trading Indonesia) anggota bisa langsung menganilisis harga sekaligus mendapatkan informasi mengenai financial sebuah perusahaan. 


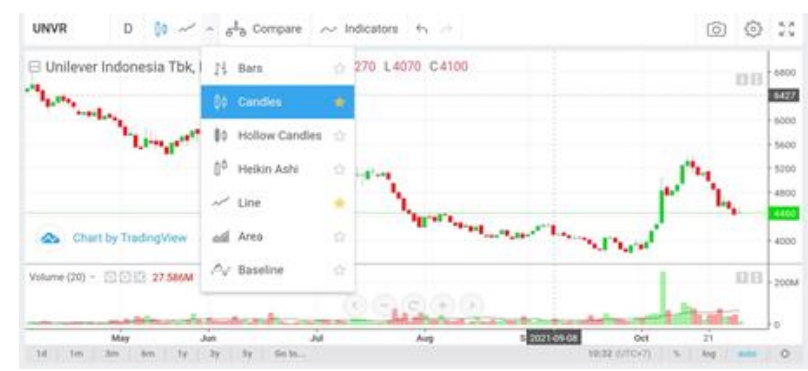

Gambar 1: Aplikasi RTI

Salah satu metode yang digunakan KSPM untuk memperkuat landasan teori yang di dapat, juga bisa dengan pengalaman, anggota akan di ajak mendaftar kan diri pada pihak sekuritas agar kemudian menjadi kan pengalaman mereka sebagai salah satu langkah menuju kesuksesan.

Terlepas dari kajian rutin setiap 6 bulan sekali pihak KSPM mengadakan kegiatan seminar sekolah pasar modal dengan menghadirkan pemateri dari BEI (Bursa Efek Indonesia)

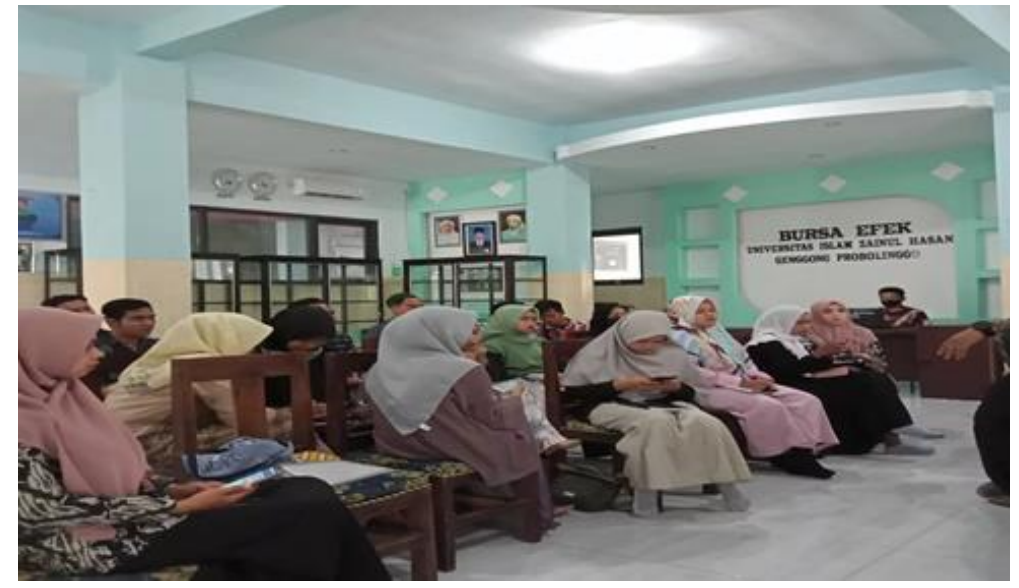

Gambar 2: Kegiatan Harian Anggota KSPM
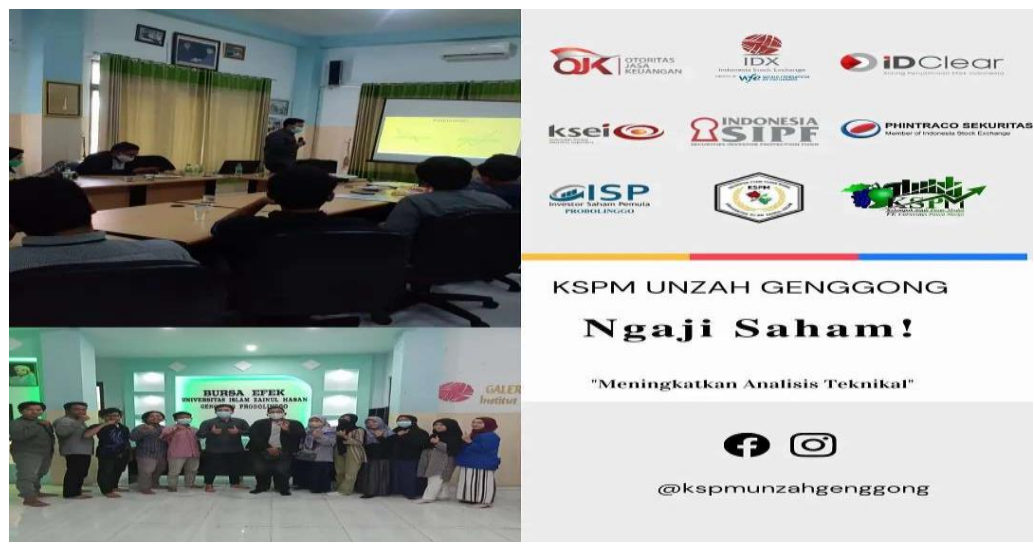

Gambar 3 


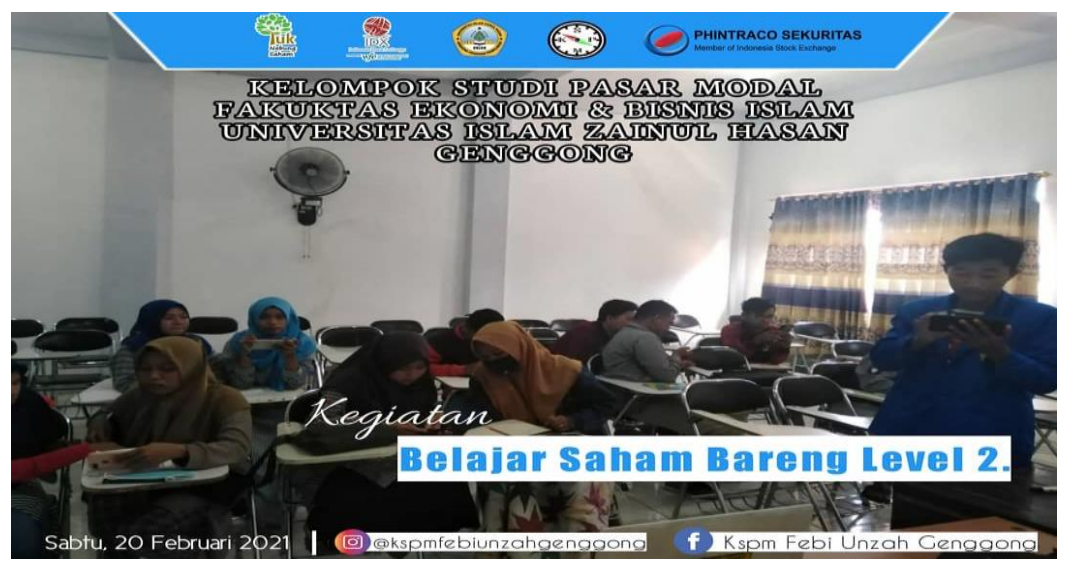

Gambar 4

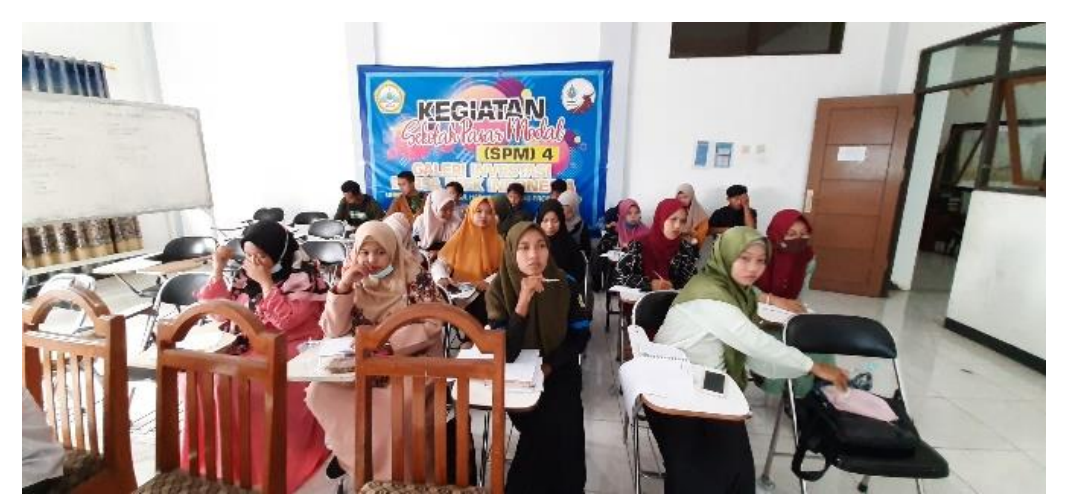

Gambar 5: Kegiatan Sekolah Pasar Modal dan Webinar dari BEI

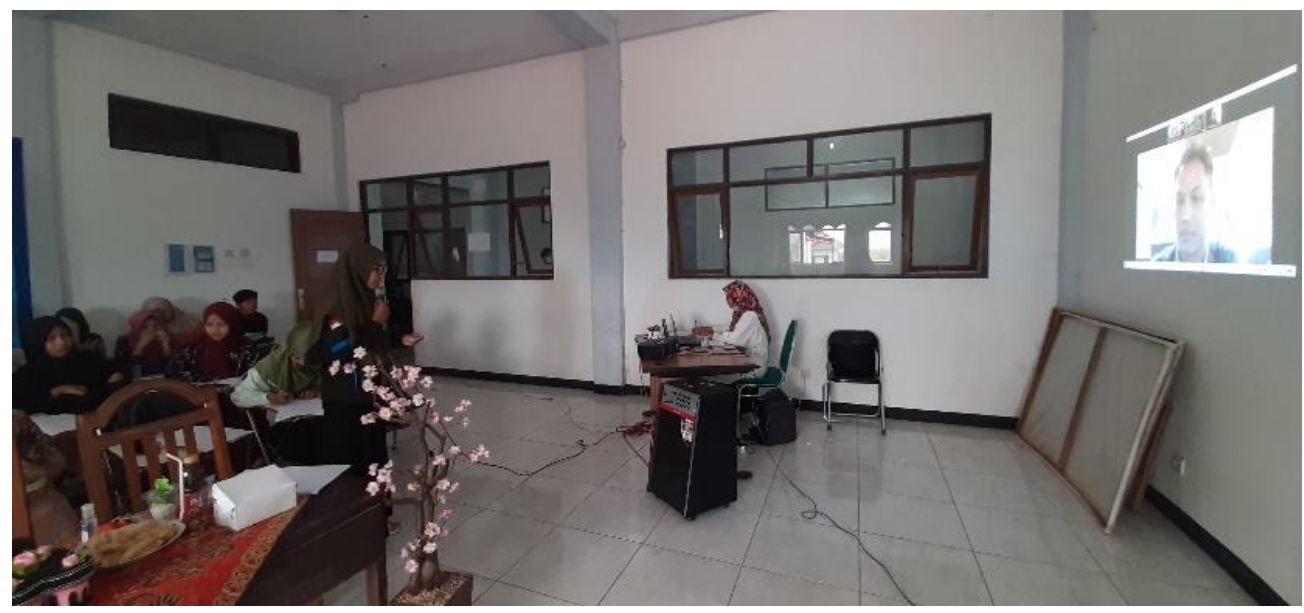

Gambar 6 


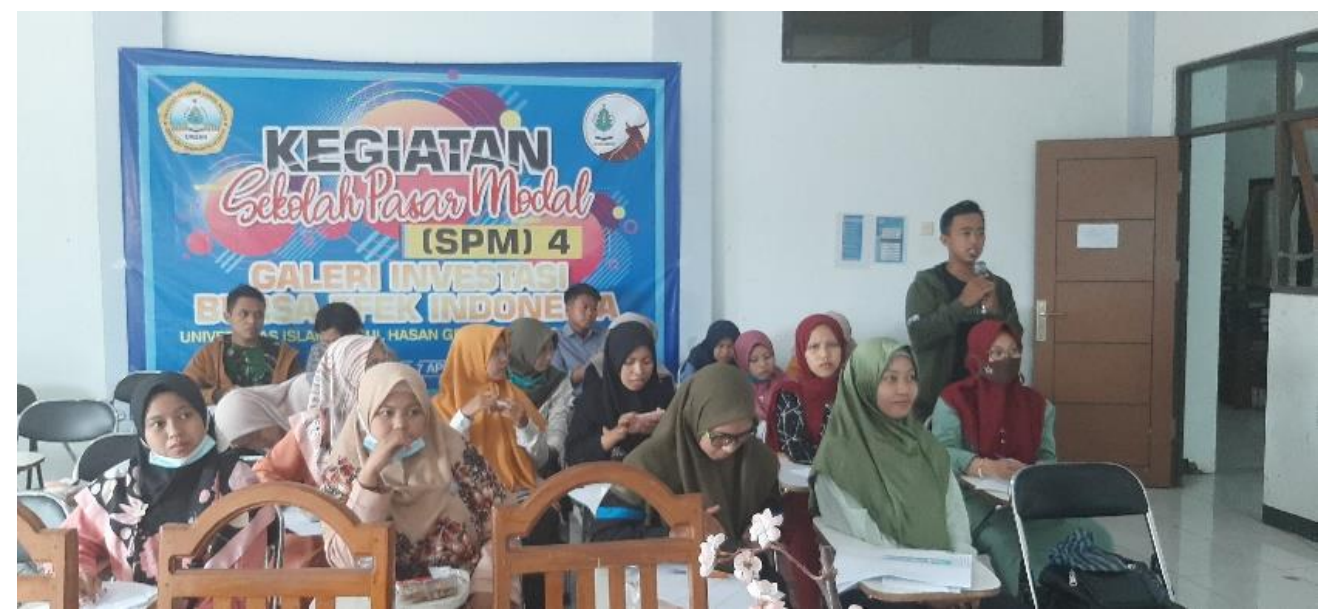

Gambar 7

\section{Kerangka Refleksi}

Seiring dengan berjalannya kegiatan pembelajaran, Perkembangan pemahaman mahasiswa mengenai pasar modal kini kian meningkat. Mayoritas dari mereka memiliki akun saham dan sudah mempraktikkan untuk melakukan trading saham. Dikalangan mahasiswa seharusnya materi Fokus on basic invesment tidak lagi menjadi perbincangan terlebih mahasiswa yang notabenenya ekonomi. Menuju Indonesia emas 2045 dengan bonus demografi yang tinggi memberikan kesempatan kepada generasi milenial dan generasi $\mathrm{Z}$ untuk menjadikan Indonesia sebagai Negara dengan perekonomian yang kuat melalui kegiatan edukasi literasi keuangan yaitu ruang lingkup pasar modal, sehingga pasar modal telah mampu direalisasikan secara merata dengan adanya kesadaran masyarakat terlebih mahasiswa malalui salah satu kegiatan edukasi pelatihan pembelajaran pasar modal dari pihak KSPM di Universitas Islam Zainul Hasan Genggong. Perkembangan mahasiswa mengenai pemahaman pasar modal pada masa kini kian meningkat dengan adanya KSPM.

\section{KESIMPULAN}

Kegiatan KSPM pada universitas Islam Zainul Hasan Genggong, menjadikan mahasiswa lebih memahami ruang lingkup pasar modal, mulai dari produk di pasar modal, pengoperasian aplikasi untuk investasi dan trading, dan sangat membantu mahasiswa dalam melakukan praktik disamping hanya teori saja yang diterima selama di bangku perkuliahan. Untuk mahasiswa diluar fakultas ekonomi dan bisnis islam, maka sebelum masuk menjadi anggota KSPM, akan diadakan training selama 3 bulan, selanjutnya ada final test untuk menentukan diterima apa tidak menjadi anggota KSPM. Untuk mahasiswa fakultas ekonomi dan bisnis islam ada post test dulu sebelum masuk menjadi anggota KSPM untuk meng test pengetahuan awal mengenai pasar modal secara umum dan mendasar. Untuk saran, harusnya kegiatan ini digaungkan lebih luas, artinya 
menjalin kerjasama yang luas degan kamous-kampus lain agar terjalin kerjasama yang baik melalui kegiatan seminar nasional misalnya, serta menjaring anggota lebih bnayak. Promosi harus digencarkan semenarik mungkin agar generasi muda tergerak hatinya untuk berinvestasi.

\section{DAFTAR PUSTAKA}

Arikunto, Suharsimi. 2002. Prosedur Penelitian Suatu Pendekatan Praktek. Jakarta : PT. Rineka Cipta.

Danim , Sudarwan.2002.Menjadi Peneliti Kualitatif Rancangan Metodologi, Presentasi, dan Publikasi Hasil Penelitian untuk Mahasiswa dan Penelitian Pemula Bidang Ilmu Sosial, Pendidikan, dan Humaniora. Bandung: Remaja Rosdakarya.

Fahmi, Irhan. 2006. Analisis Investasi dalam Perspektif Ekonomi dan politik. Bandung : PT Refika Aditama

Mawardi, M., \& Lemiyana, L. (2020). Edukasi Pasar Modal Syariah untuk Menumbuhkan Minat Investasi bagi Mahasiswa UIN Raden Fatah Palembang. Jurnal Pengabdian Pada Masyarakat, 5(2), 529-537

Modal, P. E. K. S. P., Investor, W., Indikator, D. A. P. S. S., \& Investasi, K. FAKULTAS EKONOMI DAN BISNIS ISLAM UNIVERSITAS ISLAM NEGERI WALISONGO SEMARANG.

Moleong, Lexy. J. 2000. Metodologi Penelitian Kualitatif. Bandung: PT Remaja Rosdakarya. Sudarsono, Heri. 2012. Bank dan Lembaga Keuangan Syariah. Bandung: CV Pustaka Setia Sugiyono. 2006. Metode Penelitian Pendidikan; Pendekatan Kuantitatif dan Kualitatif dan $R \& D$. Bandung: Alfabeta.

Sutedi, Adrian. 2011. Pasar Modal Syariah: sarana investasi keuangan berdasarkan prinsip syariah. Jakarta: Sinar Grafik

https://pasarmodalsyariah.com/post/66/meningkatkan-literasi-masyarakat-terkait-investasisyariah-di-pasar-modal, diakses pada tanggal 24 oktober 2021

https://katadata.co.id/lavinda/finansial/606c6eda8bcb5/kapitalisasi-pasar-modal-syariahtumbuh-28-literasinya-masih-rendah, diakses pada tanggal 24 oktober 2021

https://databoks.katadata.co.id/datapublish/2021/05/24/proporsi-populasi-generasi-z-danmilenial-terbesar-di-indonesia, diakses pada tanggal 29 oktober 2021https://www.google.com/amp/s/www.beritasatu.com/amp/ekonomi/661843/2045impian-jadi -negara-dengan-perekonomian-terkuat-tak-mustahil, diakse pada 29 oktober 2021 